〈報 告〉

\author{
薬剤師主導による antimicrobial stewardship program の導入 \\ 〜導入後 3 年間での薬剤耐性率の評価〜 \\ 佐々木康弘 ${ }^{1,7)}$ ・栗島 涁 ${ }^{2)} \cdot$ 天野 美里 ${ }^{1,7)} \cdot$ 金丸亜佑美 3.7$)$ \\ 山口 明子 ${ }^{4.7)} \cdot$ 高安 博史 ${ }^{5.7)} \cdot$ 矢野 雅隆 6.7$)$
}

\title{
Impact of Pharmacist Initiated Antimicrobial Stewardship Program $\sim$ Evaluation of Antimicrobial Resistance Rate at Three Years after Intervention
}

\author{
Yasuhiro SASAKi ${ }^{1,7)}$, Akira Kurishima ${ }^{2)}$, Misato AmanO ${ }^{1,7)}$, Ayumi KAnAmarU ${ }^{3,7)}$, \\ Akiko YAMAKUCHI ${ }^{4,7)}$, Hirobumi TAKAYASU ${ }^{5,7)}$ and Masataka YANO ${ }^{6,7)}$
}

\begin{abstract}
${ }^{1)}$ Department of Pharmacy, Tama-Nanbu Chiiki Hospital, Tokyo Metropolitan Health and Medical Treatment Corporation, ${ }^{2)}$ Department of Pharmacy, Japan Community Health Care Organization Tokyo Shinjuku Medical Center, ${ }^{3)}$ Department of Nursing, Tama-Nanbu Chiiki Hospital, Tokyo Metropolitan Health and Medical Treatment Corporation, ${ }^{4)}$ Department of Microbiological Laboratory, Tama-Nanbu Chiiki Hospital, Tokyo Metropolitan Health and Medical Treatment Corporation, ${ }^{5)}$ Department of Pediatrics, Tama-Nanbu Chiiki Hospital, Tokyo Metropolitan Health and Medical Treatment Corporation, ${ }^{6}{ }^{6}$ Department of Urology, Tama-Nanbu Chiiki Hospital, Tokyo Metropolitan Health and Medical Treatment Corporation, ${ }^{7}$ Antimicrobial Stewardship Team, Tama-Nanbu Chiiki Hospital, Tokyo Metropolitan Health and Medical Treatment Corporation
\end{abstract}

(2020 年 4 月 8 日受付 $\cdot 2020$ 年 6 月 9 日受理)

\section{要旨}

多摩南部地域病院では, 抗菌薬適正使用支援として薬剤師主導による Antimicrobial stewardship program（ASP）を導入した．導入開始後 10 ケ月での評価では第 4 世代セフェム系㧍よびカルバ ペネム系抗菌薬の投与日数は減った. しかし, 当時抗菌薬の感受性率に大きな変化はなかった. 今 回, ASP 導入後 3 年間での第 4 世代セフェム系㧍よびカルバペネム系抗菌薬の使用量と緑膿菌の 耐性率について評価した，抗菌薬の投与日数は 10 ケ月の介入後と変わらなかったが，緑膿菌の第 4 世代セフェム系抢よびカルバペ亲ム系抗菌薬の耐性率は減少した。緑膿菌の第 4 世代セフェム系 抗菌薬の耐性率と第 4 世代セフェム系抗菌薬の使用日数に有意な相関を認めた.

薬剂耐性率を減少させるためには, より長い介入が推奨される.

Key words : 抗菌薬適正使用支援, 緑膿菌, 薬剂耐性

序文

近年, 薬郕耐性菌対策として Antimicrobial stewardship programs（ASPs）が注目を浴びており, 薬剤師は ASPs の中心的役割を期待されている ${ }^{1)}$. 薬剂師による 抗菌薬適正使用支援は, $\mathrm{TDM}^{2)}$ や血液培養陽性患者へ

1) 公益財団法人東京都保健医療公社多摩南部地域病院薬剤科, 2)独 立行政法人地域医療機能推進機構東京新宿メディカルセンター薬 剂部, 3) 公益財団法人東京都保健医療公社多摩南部地域病院看護 部, 4) 公益財団法人東京都保健医療公社多摩南部地域病院検查科, 5) 公益財団法人東京都保健医療公社多摩南部地域病院小児科, 6) 公 益財団法人東京都保健医療公社多摩南部地域病院泌尿器科, 7) 公 益財団法人東京都保健医療公社多摩南部地域病院抗菌薬適正使用 支援チーム
の積極的な介入3)，コンサルテーション年等があり，副 作用回避や抗菌薬の使用量削減，費用削隇効果が得られ ている.

当院の以前の報告では薬郕師主導による ASP 導入と して第 4 世代セフェム系抗菌薬の採用医薬品整理とカル バペネム系抗菌薬の処方後監査を 2015 年 8 月に開始し, 第 4 世代セフェム系およびカルバペネム系抗菌薬の投与 日数は減ったが, 抗菌薬の感受性率に大きな変化は認め なかった5)。そこで今回, ASP 導入後 3 年間での第 4 世 代セフェム系およびカルバペネム系抗菌薬の使用量と緑 膿菌の薬郕耐性率について評価した。 
方法

公益財団法人東京都保健医療公社多摩南部地域病院は 東京都多摩市にある病床数 287 床の二次救急医療機関で あり, 感染症医は不在である. 本研究の期間は, 介入前 を 2014 年 4 月から 2015 年 7 月まで, 介入後を 2015 年 8 月から 2019 年 3 月までとした.

第 4 世代セフェム系抗菌薬とカルバペネム系抗菌薬の 抗菌薬使用量は年毎に 1000 患者あたりの投与日数 （DOT）にて算出した．抗菌薬使用密度による集計は， 処方後監査により適正投与量への変更による変動が予想 されたため, 正確な前後比較が実施できないため行って いない.

緑膿菌の薬剂耐性率は, メロペネム (MEPM) とセ フェピム（CFPM）について年毎に算出した，最小発育 阻止濃度は, MicroScan WalkAway-40plus system(ベッ クマン・コールター）を用い, 感受性は Clinical laboratory standards institute M100-S22 の判定基準に準拠し た。なお，重複処理として 30 日以内に同一患者から同 一菌が複数回検出された場合, 1 件とした。ただし， 30 日以内に同一患者から同一菌が検出された場合であって も, 検查抗菌薬感受性結果に 1 つ以上不一致がある場合 は異なる菌株として集計した。

平均在院日数抒よび全患者死亡率, 緩和ケア病棟患者 を除外した死亡率を月毎に集計した。

\section{実施した ASP}

\section{1. 採用医薬品整理}

採用医薬品整理を病院感染対策委員会と薬事委員会に 提案し, 第 4 世代セフェム系抗菌薬を 3 品目から 1 品目 に削減した，CFPM，セフォゾプラン，セフピロムのう ち, 薬価が一番低く, 第 4 世代セフェム系抗菌薬の中で 唯一発熱性好中球減少症の適応を有していたことと各種 ガイドラインでも記載があることから CFPM を選定し た.

\section{2. カルバペネム系抗菌薬の処方後監査}

MEPM，イミペネム/シラスタチン (IPM/CS) が処 方された患者を対象とし, 基質特異性拡張型 $\beta$ ラク夕 マーゼ（ESBL）産生菌などによる感染症と発熱性好中 球減少症, アレルギー等で他の抗菌薬が使用できない症 例を適切な使用と判断した。発熱性好中球減少症は, CFPM やタゾバクタム/ピペラシリン (TAZ/PIPC) も 適応を有しているが, ESBL 産生菌等の薬剤耐性グラム 陰性菌を含めた治療が必要な場合もあるため, 適切な使 用と判断した。 カルバペネム系抗菌薬以外に感受性があ る細菌による感染症や発熱性好中球減少症以外の感染症, 起因菌不明な場合, 非感染症にカルバペ亲ム系抗菌薬を 使用した場合には，不適切な使用と判断した。不適切な 使用症例へは，薬剤師が医師へ推奨抗菌薬への変更等を
提案した. その後, 提案内容は週 1 回の ICT/AST ラウ ンドにてチーム内で共有した。

\section{3. 統計解析}

第 4 世代セフェム系扔よびカルバペネム系抗菌薬の DOT は介入前後で, 分節回㷌分析 ${ }^{6)}$ 行った。 緑膿菌 の耐性率は年毎にコクランーアーミテージ傾向検定（両 側検定）にて trend（傾向変動）を算出した。耐性率に 有意差がある場合に，スピアマンの順位相関係数にて解 析した，平均在院日数および死亡率は Mann-Whitney $U$ 検定にて解析した。解析には JMP ver14.2.0を使用し, p $<0.05$ を有意差ありとした。

\section{4. 倫理審査}

本研究は公益財団法人東京都保健医療公社多摩南部地 域病院倫理委員会の承認を受けている（承認番号：3133)

\section{結果}

\section{1. 抗菌薬の変動（図 1)}

分節回帰分析において，第 4 世代セフェム系抗菌薬の DOT は ASP 導入後にすぐに減少したが $(\mathrm{p}=0.01)$, trend は-1.61 から-0.27 へ緩やかになった $(\mathrm{p}<0.01)$.

カルバペネム系抗菌薬の DOT は ASP 導入後にすぐ に減少し $(\mathrm{p}<0.01)$, trend は 0.13 から 0.006 と大きな 変化はなかった $(\mathrm{p}=0.42)$.

\section{2. 緑膿菌耐性率の变動}

CFPM の耐性率は, $25 \%$ から有意な減少を認めた（p <0.01)。また, MEPM の耐性率も有意な減少を認めた $(\mathrm{p}<0.01)$ (表 1).

CFPM 耐性率と第 4 世代セフェム系抗菌薬の DOT に 有意な相関を認めた（相関係数 $0.90, \mathrm{p}=0.04 ）$ (図 2). MEPM 耐性率とカルバペネム系抗菌薬の DOTに相関 は認められなかった（相関係数 $-0.31, \mathrm{p}=0.61$ ).

\section{3. 平均在院日数と死亡率}

平均在院日数は短縮された，全患者を対象とする死亡 率は増悪し, 緩和ケア病棟患者を除外した死亡率に大き な変化はなかった（表 2).

\section{考察}

薬片師主導によるASPs 導入後 3 年間での評価で, 緑 膿菌の CFPM と MEPM の耐性率に減少傾向を認めた. さらに, 緑膿菌の第 4 世代セフェム系抗菌薬の使用量と 耐性率に相関を認めた.

第 4 世代セフェム系抗菌薬の DOT の trend は介入前 より減少が認められ，介入により下がったが，減少傾向 は緩やかになった，介入前より強い減少傾向が認められ たことより，第 4 世代セフェム系抗菌薬の採用整理によ る効果だけでなく, 他剤の使用量に影響された等他の要 因も考えられる。本研究に抢いては, 第 4 世代セフェム 
環境感染誌 Vol. 35 no. 5, 2020

第4世代セフェム系抗菌薬

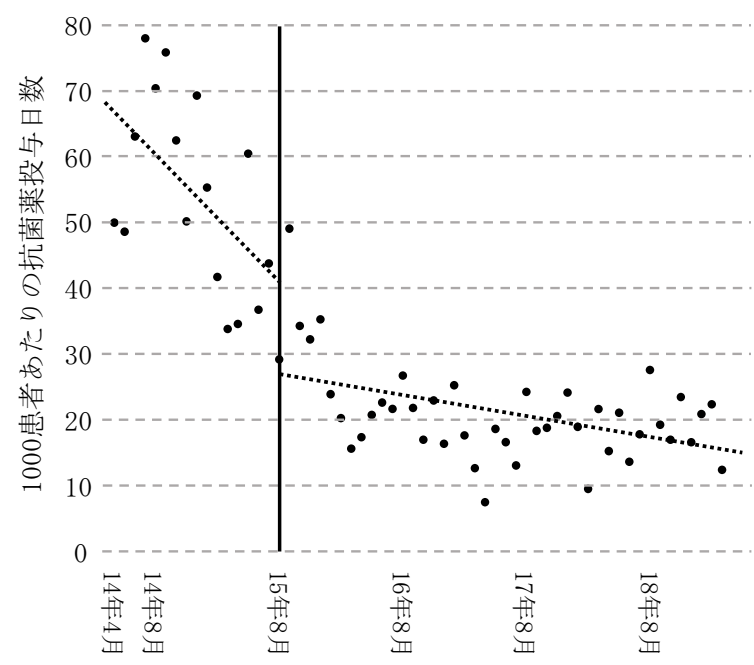

カルバペネム系抗菌薬

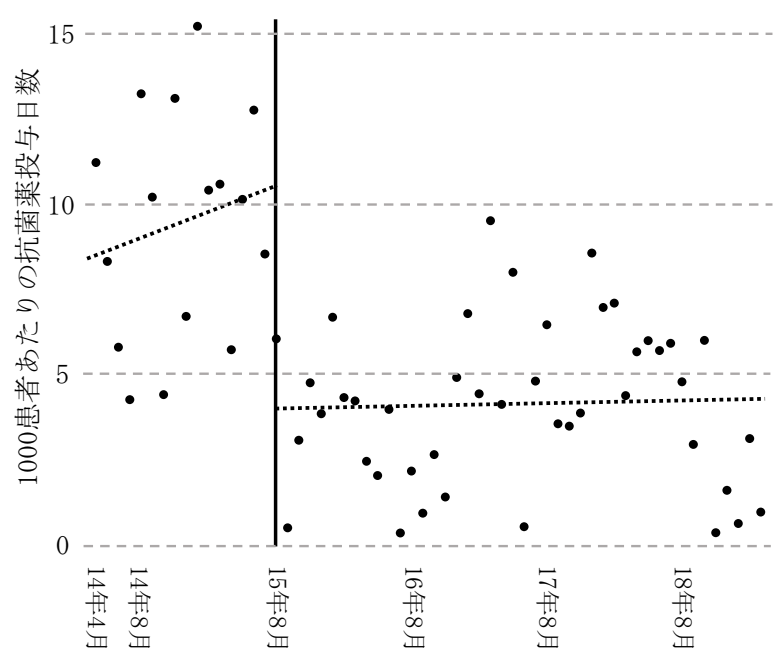

図 1 第 4 世代セフェム系とカルバペネム系抗菌薬使用推移

*分節回帰分析

表 1 緑膿菌の耐性率経年変化

\begin{tabular}{llrrrrr}
\hline \multirow{8}{*}{ 抗菌薬 } & \multicolumn{5}{c}{ 年毎の耐性菌分離数 $(\%)$} & \multirow{2}{*}{$\mathrm{p}$ 值 } \\
\cline { 2 - 5 } & \multicolumn{1}{c}{2014} & 2015 & 2016 & 2017 & 2018 & \\
\hline MEPM & $0 / 16(0)$ & $9 / 72(12.5)$ & $6 / 89(6.7)$ & $0 / 77(0)$ & $2 / 122(1.6)$ & $<0.01$ \\
CFPM & $4 / 16(25.0)$ & $15 / 73(20.5)$ & $13 / 91(14.3)$ & $7 / 78(9.0)$ & $8 / 123(6.5)$ & $<0.01$ \\
\hline *コクラン - アーミテージ傾向検定 & & & & &
\end{tabular}

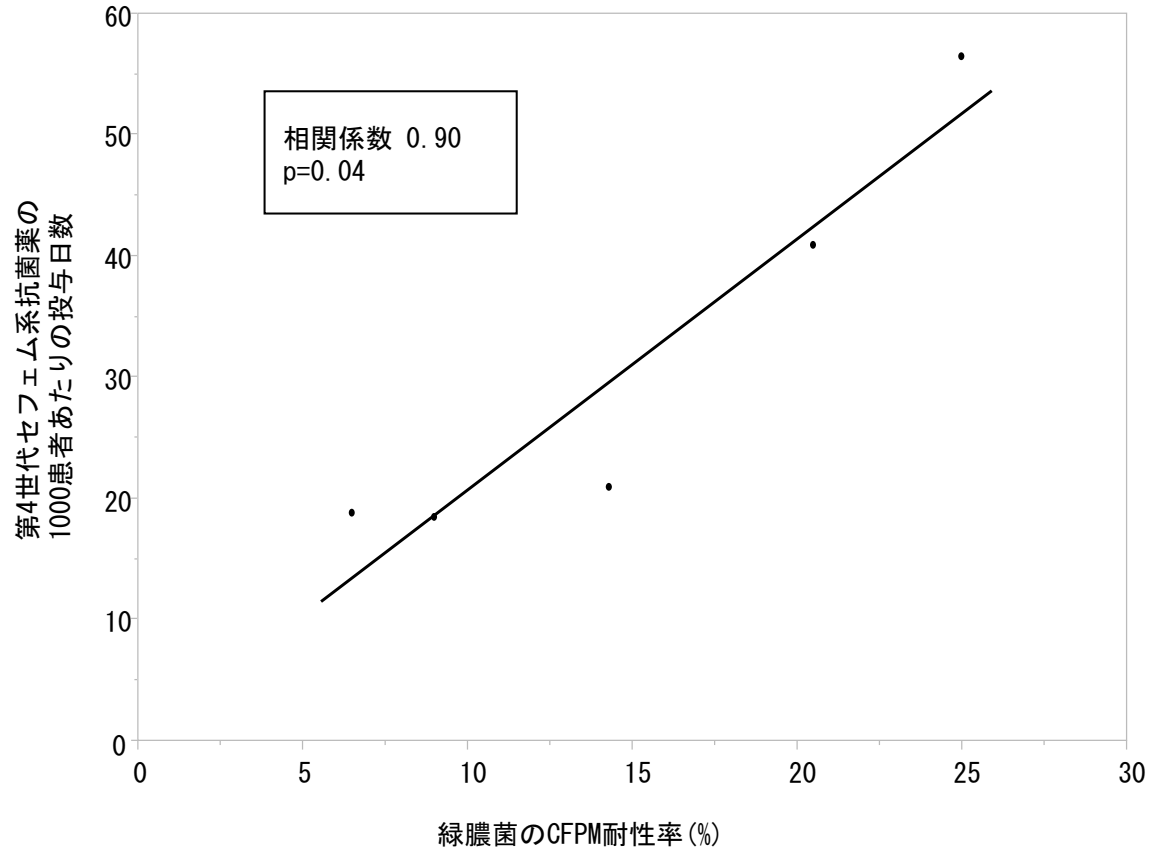

図 2 緑膿菌の CFPM 耐性率と抗菌薬投与日数の相関

*Spearman の順位相関係数 
表 2 介入前後における平均在院日数と死亡率変化

\begin{tabular}{lrrr}
\hline & \multicolumn{1}{c}{ 介入前 } & 介入後 & \multirow{2}{*}{$\mathrm{p}$ 值 } \\
\cline { 2 - 3 } & 中央值 (標準偏差) & 中央值 (標準偏差) & \\
\hline 平均在院日数 & $9.1(0.55)$ & $8.0(0.58)$ & $<0.01$ \\
1000 患者あたりの死亡率 & $3.5(0.76)$ & $4.5(1.03)$ & $<0.01$ \\
緩和ケア病棟患者を除く 1000 患者あたりの死亡率 & $2.0(0.44)$ & $2.2(0.84)$ & 0.51 \\
\hline *Mann-Whitney $U$ 検定 & & &
\end{tabular}

系とカルバペネム系抗菌薬の使用量のみを評価しており, 今後他剤の使用量も併せて検討する余地がある. カルバ ペネム系抗菌薬の DOT は, 介入直後より著減し, 低い 水準を維持することができた。

緑膿菌の耐性率は, 薬剤耐性対策アクションプランの 成果指標の一つにもなっており, 改善が期待されている. 今回の検討では, 緑膿菌の CFPM 耐性率が年々改善傾 向であり, 第 4 世代セフェム系抗菌薬の単年毎の DOT と CFPM 耐性率の相関を認めた。 セフタジジム (CAZ) や第 4 世代セフェム系, カルバペネム系, ニューキノロ ン系抗菌薬等幅広く使用届出制を導入した報告では, 導 入後 1 年で第 4 世代セフェム系抗菌薬の減少および緑膿 菌の $\mathrm{CAZ}$ 等の薬剂感受性率が改善されている7). 本研 究においても単年毎に改善が得られており, 第 4 世代セ フェム系抗菌薬は比較的早期に抗菌薬制限の効果が耐性 率に反映される可能性がある。 また, カルバペネム系抗 菌薬の耐性率は減少を認めた。第 4 世代七フェム系抗菌 薬の使用が減ることで, CFPM だけでなく MEPM や IPM/CS, TAZ/PIPC, CAZの薬剂耐性率も改善した 報告があり ${ }^{8)}$, カルバペネム系抗菌薬への監査だけがカ ルバペネム系抗菌薬への耐性率改善に寄与したのではな い可能性も考えられた. カルバペネム系抗菌薬の事前許 可制の導入有無と DOT, カルバペネム耐性緑膿菌の発 生数をみた 5 年間の多施設調査では, 事前許可制を導入 した施設は, 導入していない施設に比べて DOT は減少 し, 耐性菌発生数が減少した ${ }^{9}$. カルバペネム系抗菌薬 の事前許可制を導入していない施設の DOT は年々増加 したが，耐性菌発生数に大きな変化はなかった ため, カルバペネム系抗菌薬の相関性に関しては今回検 討した 5 年間よりも長い期間での検討の余地がある.

全患者を対象とした死亡率は増悪したが, 緩和ケア病 棟を除く死亡率は介入前後で変化がなかったため, 緩和 ケア病棟における死亡者数に強く影響したものと考えた. 緩和ケア病棟入院患者における感染症治療は, 症状緩和 に有用であるが, 延命効果に関しては期待できない ${ }^{10)}$. したがって, 今回の介入と緩和ケア病棟の死亡率増悪に 関連性は低いと考えている。緩和ケア病棟入院患者から の検出菌のうち, ESBL 産生菌は介入前で 5 件, 介入後 で 1 件であった。介入後症例は主治医の治療適応ではな
いとの判断にてカルバペネム系抗菌薬の使用はなく, 自 宅へ退院された。そのため, 今回の介入と緩和ケア病棟 の死亡率増悪に関連性は低いと考えている。平均在院日 数や死亡率は, Clostridioides difficile 感染症等院内感染 症によって影響されるため ${ }^{11)}$, 抗菌薬の使用量のみでは 評価は難しいが, 本研究の ASPにおいて, 不適切な抗 菌薬治療による治療期間の延長, その結果として平均在 院日数の延長や死亡率の増加がないことが本研究の ASP が不適切な介入でなかった指標の一つであり, 安 全にASPが導入できたと考えている.

本研究の限界は, 複数ある. 単施設で実施している点 と第 4 世代セフェム系拉よびカルバペネム系抗菌薬のみ の評価に留まっている点, 2014 年の検体数が限られて いることである.

最後に，第 4 世代セフェム系抗菌薬の採用医薬品整理 とカルバペネム系抗菌薬の処方後監査を導入し, 中期的 な評価にて緑膿菌の第 4 世代セフェム系およびカルバペ ネム系抗菌薬の耐性率が改善したことがわかった．薬歳 耐性対策は急務ではあるが，薬剤耐性率は短期的な評価 では改善が期待できず，中・長期的な視点が必要である。 本研究が, 感染症専門医が不在の施設での抗菌薬適正使 用推進の一助となることを期待する.

利益相反自己申告：申告すべきものなし．

\section{文献}

1）門田淳一, 岩田 敏, 賀来満夫, 太田 茂, 佐々木均, 上 野和之, 他：抗菌薬の適正使用に向けた 8 学会提言 抗菌 薬適正支援（Antimicrobial Stewardship：AS）プログラム 推進のために.日化療会誌 2016; 64(3): 379-85.

2）佐々木康弘, 金丸亜佑美, 内田壽恵, 矢野雅隆, 多田博史 : 術後にメチシリン耐性 Staphylococcus lugdunensis による 髄膜炎をおこした 1 例。臨床神経 2016; 56(11): 773-6.

3）田中広紀, 田口和三, 平林麻里, 並木美加子, 宇賀神利久, 丸茂健治, 他：血液培養陽性患者一の積極的介入と抗菌薬 の de-escalation 療法による医療経済効果. 日病薬誌 2011; 47(3): 301-3.

4) Waters CD: Pharmacist-driven antimicrobial stewardship program in an institution without infectious diseases physician support. Am J Health Syst Pharm 2015; 72(6): 466-8.

5）佐々木康弘，金丸带佑美，山口明子，矢野雅隆：薬剂師主 導による antimicrobial stewardship program の導入. 環境 感染誌 2017; 32(6): 369-73. 
6) Wagner AK, Soumerai SB, Zhang F, Ross-Degnan D: Segmented regression analysis of interrupted time series studies in medication use research. J Clin Pharm Ther 2002; 27(4): 299-309.

7）田中 大, 深澤鈴子, 喜古康博，木下かおり，坂口及きよ， 藤江俊秀 : 抗菌薬の幅広い使用届出性が処方動向及び薬剂 感受性に及ぼす効果. 環境感染誌２008; 23(5): 361-4.

8) Djordjevic ZM, Folic MM, Jankovic SM: Correlation between cefepime utilization and Pseudomonas aeruginosa resitance rates to $\beta$-lactams and carbapenems in patients with healthcare-associated infections. J Glob Antimicrob Resist 2018; 13: 60-4.

9) Pakyz AL, Oinonen M, Polk RE: Relationship of carbapenem restriction in 22 university teaching hospitals to carbapenem use and carbapenem-resistant Pseudomonas aeruginosa. Antimicrob Agents Chemother 2009; 53(5): 1983-6.

10) Clayton J, Fardell B, Hutton-Potts J, Webb D, Chye R: Parenteral antibiotics in a palliative care unit: prospective analysis of current practice. Palliat Med 2003; 17(1): 44-8.

11) van Kleef E, Green N, Goldenberg SD, Robotham JV, Cookson B, Jit M, et al: Exess length of stay and mortality due to Clostridium difficile infection: a multi-state modelling approach. J Hosp Infect 2014; 88(4): 213-7.

〔連絡先：`206-0036 東京都多摩市中沢 2-1-2 公益財団法人東京都保健医療公社多摩南部地域病院薬剤 科 佐々木康弘

E-mail: yasuhiro_sasaki1@tokyo-hmt.jp]

\title{
Impact of Pharmacist Initiated Antimicrobial Stewardship Program $\sim$ Evaluation of Antimicrobial Resistance Rate at Three Years after Intervention
}

\author{
Yasuhiro SASAKI ${ }^{1,7)}$, Akira KURISHIMA ${ }^{2)}$, Misato AMANO ${ }^{1,7)}$, Ayumi KANAMARU ${ }^{3,7)}$, \\ Akiko YAMAKUCHI ${ }^{4,7)}$, Hirobumi TAKAYASU ${ }^{5,7)}$ and Masataka YANO ${ }^{6,7)}$
}

\begin{abstract}
${ }^{1)}$ Department of Pharmacy, Tama-Nanbu Chiiki Hospital, Tokyo Metropolitan Health and Medical Treatment Corporation, ${ }^{2)}$ Department of Pharmacy, Japan Community Health Care Organization Tokyo Shinjuku Medical Center, ${ }^{3)}$ Department of Nursing, Tama-Nanbu Chiiki Hospital, Tokyo Metropolitan Health and Medical Treatment Corporation, ${ }^{4)}$ Department of Microbiological Laboratory, Tama-Nanbu Chiiki Hospital, Tokyo Metropolitan Health and Medical Treatment Corporation, ${ }^{5)}$ Department of Pediatrics, Tama-Nanbu Chiiki Hospital, Tokyo Metropolitan Health and Medical Treatment Corporation, ${ }^{6)}$ Department of Urology, Tama-Nanbu Chiiki Hospital, Tokyo Metropolitan Health and Medical Treatment Corporation, ${ }^{7)}$ Antimicrobial Stewardship Team, Tama-Nanbu Chiiki Hospital, Tokyo Metropolitan Health
\end{abstract} and Medical Treatment Corporation

\section{Abstract}

In Tama-Nanbu Chiiki Hospital, a pharmacist-initiated antimicrobial stewardship program was started to optimize the use of antimicrobial agents in the hospital. Previously, at 10 months after the start of the program, the therapy durations for both $4^{\text {th }}$ cephem and carbapenem were shortened. However, at that time, the resistance rate of Pseudomonas aeruginosa for both agents did not markedly change. Currently, we evaluated the correlation between the resistance rate of Pseudomonas aeruginosa and above mentioned antibiotics at 3 years after intervention. Although the day of therapy (DOT) was almost the same as that at 10 months of intervention, we achieved decreased resistance of Pseudomonas aeruginosa for both antibiotics. A positive correlation was observed between $4^{\text {th }}$ cephem resistance rate in Pseudomonas aeruginosa and DOT $(0.90, \mathrm{p}=0.04)$.

To reduce the antimicrobial resistance rate, a longer period of intervention is recommended.

Key words: antimicrobial stewardship, Pseudomonas aeruginosa, Antimicrobial resistance 